\title{
Peningkatan Literasi Dengan Strategi The Cognitive Academic Language Learning Approach (CALLA) Di Ruang Baca Tanah Ombak Dan Lentera Kuning
}

\author{
Witri Annisa ${ }^{1}$, Rio Rinaldi ${ }^{2}$, Ade Fitri Rahmadani ${ }^{3}$ \\ ${ }^{12}$ Prodi Pendidikan Bahasa Indonesia, FKIP, Universitas Bung Hatta Padang \\ ${ }^{3}$ Prodi Pendidikan Teknologi Informasi dan Komputer, FKIP, Universitas Bung Hatta Padang \\ ${ }^{1}$ witriannisa87@bunghatta.ac.id \\ 2rinaldirio83@yahoo.co.id \\ 3adefitrirahmadani@gmail.com
}

\begin{abstract}
ABSTRAK
Salah satu kegiatan yang dapat meningkatkan minat baca adalah membudayakan kegiatan literasi dikalangan anak-anak. Upaya yang dapat dilakukan adalah menyediakan sarana dan prasarana literasi anak. Beberapa komunitas di masyarakat di Kota Padang sudah mencanangkan budaya literasi, diantaranya Komunitas Tanah Ombak dan Komunitas Lentera Kuning. Komunitas Tanah Ombak sebagai mitra 1 dan Komunitas Lentera Kuning sebagai mitra 2 sudah mencangkan budaya literasi dengan menyediakan sarana perpustakaan. Buku-buku diperpustkaan banyak dibaca anak-anak, tetapi kegiatan membaca tersebut hanya untuk bermain. Kegiatan membaca akan lebih bermakna jika dikaitkan dengan pengetahuan sehingga dapat menunjang kemampuan akademik anak-anak Tanah Ombak dan Lentera Kuning. Metode yang dilakukan untuk mengatasi permasalahan yang dihadapi mitra dilakukan dengan pembinaan kegiatan membaca yang bermakna dengan menerapkan strategi Cognitive Academic Language Learning Approach (CALLA). Hasil dari kegiatan tersebut cukup baik, yaitu adanya peningkatan rata-rata kemampuan membaca pemahaman dari sebelum dan sesudah dilaksanakan kegiatan literasi dengan Strategi CALLA..
\end{abstract}

Kata kunci: literasi, Strategi CALLA, Tanah Ombak, Lentera Kuning

\section{PENDAHULUAN}

Kegiatan membaca merupakan salah satu bentuk perwujudan literasi yang penting dibidang pendidikan. Pendidikan pada masyarakat berpengaruh besar pada tingkat kualitas sumber daya manusia suatu bangsa. Bangsa yang berkualitas juga memiliki kualitas pendidikan yang tinggi. Namun, berdasarkan data Badan Pusat Statistik (BPS) tentang Indeks Pembangunan Manusia (IPM) Indonesia tahun 2013, IPM Indonesia sebesar 68,4 dan berada pada peringkat 108 dari 187 negara, serta peringkat ke-5 di ASEAN (Suharyanto, 2015). Salah satu faktor penyebab rendahnya IPM Indonesia adalah rendahnya kualitas pendidikan. Dengan demikian, upaya yang komprehensif perlu dilakukan untuk meningkatkan kualitas pendidikan. Upaya yang dapat dilakukan adalah melalui peningkatan kualitas litarasi dibidang pendidikan pada masyarakat.

Literasi pada masyarakat dapat berwujud dalam taman baca masyarakat (TBM). Pada umumnya, TBM pada masyarakat sudah melaksanakan kegiatan literasi. Namun, kegiatan membaca yang dilakukan sebagai wujud literasi belum belum terlaksana dengan efektif. Oleh karena itu, pengelola TBM memerlukan upaya yang komprehensi agar kegiatan literasi tersebut terlaksana dengan efektif.

Jika kegiatan membaca terlaksana dengan efektif, masyarakat akan memperoleh manfaat. Kebermanfaatan kegiatan tersebut perlu memperhatikan tujuan dan metode membaca yang tepat. Cara membaca dan tujuan membaca dapat diupayakan dengan mengedukasi kelompok belajar pada TBM.

Kegiatan membaca di TBM akan bermanfaat jika masyarakat memiliki minat baca. Minat baca yang baik akan berpengaruh pada tingkat pemahaman terhadap bacaan. Proses memahami bacaan berhubungan erat dengan proses kognitif. Dengan demikian, proses kognitif tidak dapat dipisahkan dalam proses kegiatan membaca pemahaman. Selain kemampuan kognitif, dukungan kemampuan metakognitif juga akan membuat masyarakat lebih cepat dan efisien dalam memahami bacaan.

Kegiatan membaca yang tepat dapat dilakukan di TBM dengan memilih strategi 
yang menarik dan menyenakan sehingga dapat memotivasi kelompok belajar untuk membaca. Salah satu yang dapat dilakukan adalah dengan melaksanakan strategi CALLA. Strategi tersebut basis kognisi dengan tidak melupakan aspek metakognisi ini. Dengan kegiatan yang berbeda dari sebelum, pembaca lebih mudah berpikir dan tidak dibebani dengan keterpaksaan membaca. Strategi CALLA dapat diterapkan dalam kegiatan bahasa, matematika, dan sains. Hasil penelitian yang penerapan strategi CALLA, antara lain Marimuthu, $\mathrm{R}$, Chittra Muthusamy, dan Jeyamahla Veeravagu (2011) menyatakan stategi metakognisi dalam CALLA pada pembelajaran membaca pemahaman bahasa Inggris menunjukkan hasil yang lebih baik sehingga dapat meningkatkan kemampuan membaca pemahaman siswa. Hasil yang sama juga ditunjukkan dalam penelitian Annisa (2017) bahwa Strategi CALLA dapat meningkatkan kemampuan membaca pemahaman siswa yang cukup signifikan, yaitu mencapai 0,000 yang berarti $>$ $\alpha 0,05$. Artinya, pembelajaran membaca pemahaman efektif dengan menerapkan strategi CALLA berbasis kearifan lokal.

Strategi CALLA dapat diterapkan dalam pembelajaran bahasa, yaitu pembelajaran membaca pemahaman. merupakan salah satu strategi dalam pembelajaran membaca pemahaman. Menurut Chamot (1995) tahapan dalam strategi CALLA dapat dilakukan melalui lima tahap, yaitu persiapan, presentasi, praktik, evaluasi, dan tindak lanjut. Annisa (2017) menjelaskan lima tahap strategi CALLA tersebut. Tahap pertama, yaitu tahap persiapan. Tahap ini dilakukan beberapa kegiatan prabaca dimulai dengan mengidentifikasi dan merefleksikan pengetahuan sebelum mengenal teks yang akan dibaca seperti melakukan skemata dengan mengidentifikasi pengetahuan perihal tema teks yang akan dibaca, memberikan beberapa informasi tentang teks kemudian diminta untuk mengemungkakan pengetahuan tentang informasi tersebut. Selanjutnya, diberikan teks lalu ditugaskan untuk mengidentifikasi melihat judul, bagian awal, dan membaca sekilas teks tersebut, kemudian diminta untuk mengemungkakan prediksi isi teks secara umum dan menanyakan alasan tentang prediksi tersebut. Terkahir, menanyakan kepada tentang tujuan membaca teks tersebut dengan mencatatnya dijurnal.

Tahap kedua, yaitu tahap presentasi. Tahap ini dilakukan dengan memberi informasi baru yang berhubungan dengan teks yang akan dibaca melalui media-media yang menarik.

Tahap ketiga, yaitu tahap praktik. Tahap ini dilakukan dengan aktif membaca dalam hati dan mulai berlatih menemukan informasi baru. Selanjutnya, untuk memahami isi teks dilakukan diskusi kelompok perihal teks yang telah dibaca. Dalam kegiatan kelompok tersebut, pemimpin diskusi mengemungkakan rangkuman teks berdasarkan pemahamannya kemudian mendiskusikan ketepatan isi teks dan kesulitan dalam memahami teks dalam kelompok. Selanjutnya, dibuat kesimpulan secara kelompok perihal isi teks.

Tahap keempat, yaitu tahap evaluasi. Tahap ini dilakukan dengan mengevaluasi teks tersebut dengan membandingkan skemata, informasi baru, dan informasi baru tentang isi teks.

Tahap kelima, yaitu tahap tindak lanjut. Tahap ini merupakan tahap pascabaca dengan menentukan kesimpulan dari kegiatan membaca dengan ketercapaian tujuan membaca yang telah ditentukan sebelumnya.

Menurut Abidin (2010) ada beberapa faktor yang memengaruhi keberhasilan pemahaman bacaan, antara lain pengetahuan sebelumnya, struktur teks, dan strategi pembaca dalam memproses bacaan. Dengan demikian, kegiatan membaca dengan strategi CALLA dapat dilakukan sehingga dapat meningkatkan kemampuan membaca pemahaman kelompok belajar di TBM.

$$
\text { Penerapan strategi CALLA }
$$

dilaksanakan pada dua TBM dalam rangka pengabdian kepada masyarakat, yaitu TBM Tanah Ombak dan Lentera Luning. Pemilihan kedua TBM tersebut didasarkan karena sudah melaksanakan kegiatan literasi. Berikut uraian tentang kedua TBM tersebut.

\section{Tanah Ombak}

Tanah Ombak merupakan sebuah komunitas atau gerakan literasi (membaca) bagi anak-anak sekitar Purus dan anak sekolah menengah di Kota Padang, Sumatra Barat. Komunitas ini dikomandoi oleh Yusrizal KW dan Suhendry. Lokasi komunitas ini di Jalan Purus III Padang Sumatra Barat. Berada di kawasan kampung nelayan dengan rumahrumah berjubel dan kumuh itu dihuni warga yang kebiasaan buruk. Masyarakat dewasanya gemar berjudi dan mengonsumsi minuman keras, sedangkan anak-anak tumbuh di tengah caci-maki sehari-hari. Bahkan mereka sudah 
terbiasa "ngelem", mengisap aroma lem yang mengandung alkohol.

Awalnya, Suhendri dan Yusrizal KW ingin mengajari anak-anak itu mencintai seni. Mulai dengan belajar teater, Suhendri sebagai sutradara menggabung kepintaran mereka joged dangdut dengan gerakan dramaturgi. Yusrizal KW menyediakan buku-buku agar mereka mau membaca dan diajar menceritakan kembali. Dari jumlah kecil, akhirnya anakanak yang lain tertarik dan bergabung. Tantangannya cukup berat, datang dari para orang tua yang merasa penghasilannya menurun. Sebab, anak-anak yang tak jelas pendidikannya itu sudah dipaksa bekerja mencari uang dengan cara apa saja.

Bulan Oktober 2015, Suhendri meminta izin kepada mertuanya yang tinggal di rumah itu agar rumahnya dijadikan sanggar. Demi tujuan baik itu, permintaan Suhendri dipenuhi. Sejak itu ada ruangan seluas $5 \times 7$ meter dijadikan tempat serbaguna. Merapat ke dinding terdapat rak-rak buku. Di dinding yang lain tertempel beberapa lukisan anak-anak itu. Perlahan-lahan perilaku anak-anak itu berubah positif. Kebiasaan berucap kotor dan berkelahi antarmereka berkurang bahkan dalam setahun berganti dengan kekerabatan dan berlaku sopan, saling menghormati. "Ada 4 syarat untuk bergabung ke Tanah Ombak," ujar Suhendri. "Pertama, tidak boleh berbicara kasar. Kedua, dilarang main fisik. Ketiga, harus menjaga kebersihan sanggar dan lingkungan. Keempat, belajar menyimak materi dan menceritakan kembali."

Komunitas Tanah Ombak sudah mencanangkan budaya literasi dengan menyediakan sarana perpustakaan. Menurut Yusrizal KW, di perpustakaan Tanah Ombak terdapat sekitar 3000-an buku merupakan koleksi pribadi dan sumbangan dari berbagai pihak. Koleksi tersebut terdiri atas $80 \%$ buku fiksi anak, $10 \%$ buku fiksi dewasa, dan $20 \%$ buku nonfiksi.

Dengan disediakanya sarana perpustakaan di Tanah Ombak, anak-anak bisa membaca secara bebas. Akan tetapi, banyak anak yang membaca hanya untuk bermain. Kegiatan membaca akan lebih bermakna jika dikaitkan dengan pengetahuan sehingga dapat menunjang kemampuan akademik anak-anak Tanah Ombak. Budaya literasi yang sudah tercipta perlu dilakukan pembinaan agar terpola dan kontiniu sehingga kegiatan membaca lebih bermakna.

Dengan berbagai permasalahan yang diuraikan sebelumnya, perlu dilakukan upaya mengatasi masalah tersebut. Upaya yang dapat dilakukan antara lain: melakukan pembinaan kegiatan membaca yang bermakna dengan menerapkan strategi CALLA. Dengan memiliki kemampuan membaca yang baik melalui strategi CALLA, kualitas kegiatan membaca anak-anak di Tanah Ombak dapat lebih bermakna dan sekaligus dapat menunjang kemampuan akademik

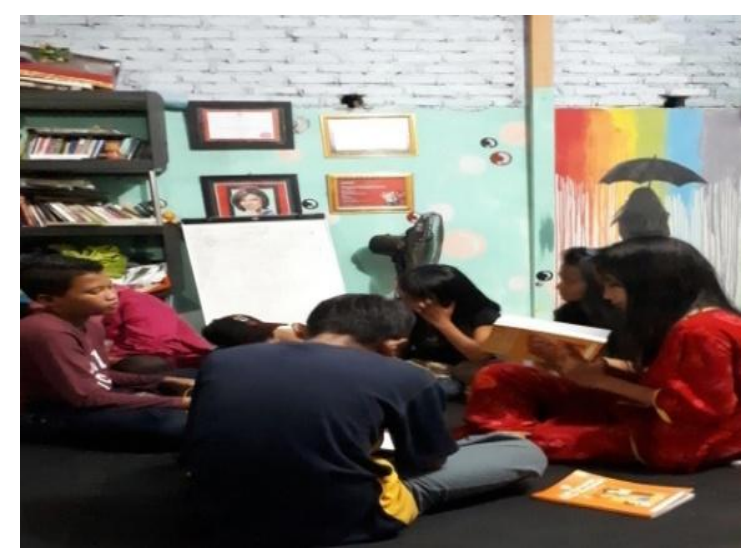

Gambar 1 Kegiatan Membaca di Tanah

Ombak

\section{Lentera Kuning}

Lentera Kuning merupakan sebuah komunitas atau gerakan literasi (membaca) bagi anak-anak sekitar Masjid Taqwa Muhammadyah Kota Padang dibawah naungan PW IPM Sumatra Barat yang dipimpin oleh Roza Reflina. Pembentukan komunitas ini didukung dan diresmikan oleh Kemendikbud RI pada awal 2017. Komunitas ini diketua oleh Anton Risno yang juga sebagai anggota PW IPM Sumatra Barat. Sekretariat komunitas ini berada di lantai dasar Masjid Taqwa Muhammadyah Padang, Jalan Bundo Kandung, tepatnya di kawasan Pasar Raya Padang.

Pembentukan komunitas ini terjadi karena para pengurus PW IPM Sumatra Barat menggalakkan budaya literasi pada masyarakat Kota Padang. Sasaran komunitas ini adalah anak-anak putus sekolah, mahasiswa, dan masyarakat umum di Kota Padang. Program kerja komunitas ini difokus pada kegiatan literasi. Pertama, perpustakaan, komunitas ini sudah memiliki koleksi lebih dari 1000 buku yang terdiri atas berbagai bidang. Komunitas ini mendapatkan sumbangan buku dari berberapa donatur, seperti guru, dosen, dan masyarakat umum dari Sumatra Barat. Kedua, teras baca, kegiatan ini berupa masyarakat dibolehkan membaca dan meminjam buku gratis di lapak yang mitra buka di kawasan GOR H. Agus Salim. Teras baca dilaksakan secara rutin setiap minggu. Ketiga, kelompok diskusi, kelompok ini membahas isu hangat 
baik nasional maupun internasional yang berbasis literasi.

Berdasarkan wawancara dengan salah satu pengurus Komunitas Lentera Kuning, ada beberapa kendala yang mitra hadapi dalam mejalankan program kerja mereka tersebut. Kegiatan membaca yang dilakukan pengguna dilakukan secara bebas. Masyarakat yang membaca buku di Lentera Kuning hanya untuk mengisi waktu. Padahal, kegiatan membaca akan lebih bermakna jika dikaitkan dengan pengetahuan sehingga dapat menunjang kemampuan akademik dan meningkatkan wawasan masyarakat.

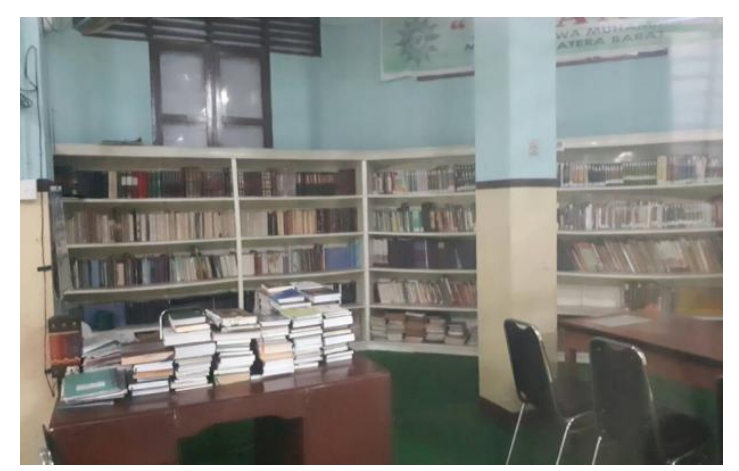

Gambar 2 Kondisi Perpustakaan Komunitas Lentera Kuning

\section{METODE KEGIATAN}

Metode pelaksanaan program ini menjadi dasar acuan bagi tim dalam menjalankan seluruh kegiatan yang telah ditetapkan. Oleh karena itu, dibutuhkan tahapan metode pelaksanaan yang kongkret dan tepat. Adapun tahapan prosedur tersebut antara lain

1) Tahap persiapan. Tahapan ini diperlukan oleh tim pengusul untuk menyiapkan halhal apa saja yang menjadi kebutuhan pelaksanaan program. Tahapan ini diawali dengan survei dan wawancara langsung dengan masyarakat yang dalam hal ini adalah mitra 1 dan mitra 2 .

2) Tahap pelaksanaan program. Tahapan ini dilakukan berdasarkan bidang keahlian masing-masin. Namun, tetap dalam pelaksanaannya seluruh tim terlibat.

3) Tahap evaluasi. Tahapan ini dilakukan oleh tim sebagai bentuk komitmen dalam menunjang keefektifan program. Selain itu, melalui evaluasi inilah indikator pencapaian dapat terukur.

4) Tahap pelaporan. Tahapan ini disusun oleh tim sebagai bentuk pertanggungjawaban atas usulan serta pelaksanaan keseluruhan kegiatan dalam program PKM.
5) Tahap keberlanjutan. Tahapan terakhir ini diperlukan tidak hanya oleh kedua mitra program, namun diperuntukan pula oleh tim pengusul sebagai bentuk komitmen tinggi dalam menjalankan Tri Dharma Perguruan Tinggi dalam bidang pengabdian masyarakat.

\section{HASIL \& PEMBAHASAN}

Program ini telah terlaksana pada mitra 1, yaitu Tanah Ombak pada tanggal 2 Maret 2018. Kegiatan ini diikuti oleh sebelas orang anak komunitas yang terdiri dari berbagai tingkatan sekolah (SD, SMP, dan SMK).

Sebelum dilaksanakan kegiatan literasi dengan Strategi CALLA, anak-anak komunitas diuji kemampuan membaca pemahamannya melalui tes membaca pemahaman sebanyak lima belas butir soal. Tujuan tes tersebut dilakukan untuk mengukur kemampuan awal anak-anak komunitas dalam membaca pemahaman teks. Hasil tes tersebut dikumpulkan dan dilanjutkan dengan kegiatan literasi dengan Strategi CALLA.

Pelaksanaan strategi CALLA dilakukan dalam lima tahap strategi CALLA. Tahap pertama yaitu tahap persiapan. Tahap ini dilakukan beberapa kegiatan prabaca dimulai dengan mengidentifikasi dan merefleksikan pengetahuan sebelum mengenal teks yang akan dibaca seperti melakukan skemata dengan mengidentifikasi pengetahuan perihal tema teks yang akan dibaca, yaitu tauran pelajar, memberikan beberapa informasi tentang teks kemudian diminta untuk mengemungkakan pengetahuan tentang informasi tauran pelajar tersebut. Selanjutnya, diberikan teks lalu ditugaskan untuk mengidentifikasi melihat judul, bagian awal, dan membaca sekilas teks tersebut, kemudian diminta untuk mengemungkakan prediksi isi teks secara umum dan menanyakan alasan tentang prediksi tersebut. Terkahir, menanyakan kepada tentang tujuan membaca teks tersebut dengan mencatatnya dijurnal. Tahap ini diikuti oleh anak-anak komunitas dengan aktif yang terlihat dari banyaknya yang berpastisipasi dalam Tanya jawab.

Tahap kedua, yaitu tahap presentasi. Tahap ini dilakukan dengan memberi informasi baru yang berhubungan dengan teks yang akan dibaca melalui media-media yang menarik. Pemberian media-media yang menarik dilakukan dengan menampilkan 
gambar-gambar yang berhubungan dengan teks, yaitu gambar tauran.

Tahap ketiga, yaitu tahap praktik. Tahap ini dilakukan dengan aktif membaca dalam hati dan mulai berlatih menemukan informasi baru. Selanjutnya, untuk memahami isi teks dilakukan diskusi kelompok perihal teks yang telah dibaca. Dalam kegiatan kelompok tersebut, pemimpin diskusi mengemungkakan rangkuman teks berdasarkan pemahamannya kemudian mendiskusikan ketepatan isi teks dan kesulitan dalam memahami teks dalam kelompok. Selanjutnya, dibuat kesimpulan secara kelompok perihal isi teks.

Tahap keempat, yaitu evaluasi. Tahap ini dilakukan dengan mengevaluasi teks tersebut dengan membandingkan skemata, informasi baru, dan informasi baru tentang isi teks. Tahap ini dilakukan dengan antusia oleh anak-anak komunitas dengan mengumpulkan semua informasi yang mereka peroleh dari sebelum, sedang, dan setelah membaca teks tentang tauran pelajar.

Tahap kelima, yaitu tahap tindak lanjut. Tahap ini merupakan tahap pascabaca dengan menentukan kesimpulan dari kegiatan membaca dengan ketercapaian tujuan membaca yang telah ditentukan sebelumnya.

Setiap akhir pelaksanaan kegiatan literasi strategi CALLA, kembali dilakukan tes. Tes ini dilakukan untuk mengukur perkembangan peningkatan kemampuan membaca pemahaman anak-nak komunitas. Selain itu, tujuan tes ini juga dilakukan melatih anak-anak komunitas agar dapat mengaplikasikan kegiatan tersebut di sekolah.

Berikut foto-foto kegiatan membaca dengan Startegi CALLA di Tanah Ombak.

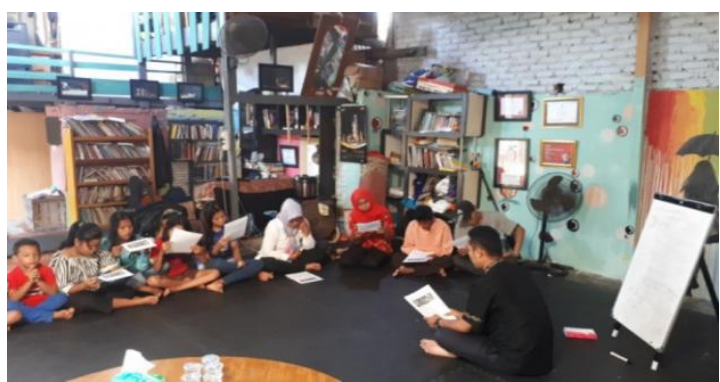

Gambar 3. Kegiatan Tahap 3 Praktik Membaca dalam Startegi CALLA

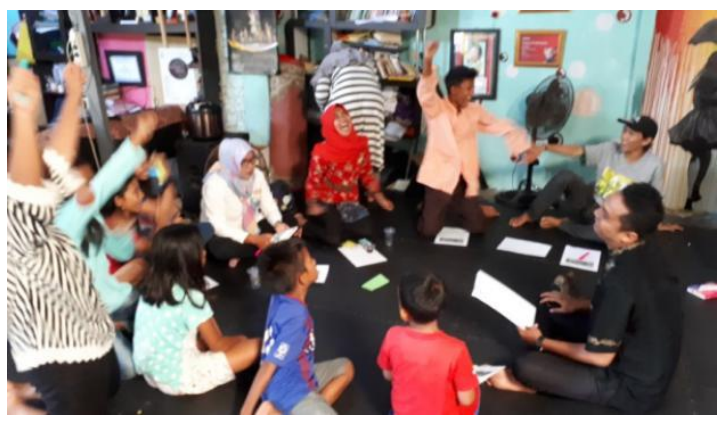

Gambar 4. Kegaitan Tahap 4 Evaluasi (antusias dalam mengevaluasi teks yang telah dibaca dengan skemata) dalam Startegi CALLA

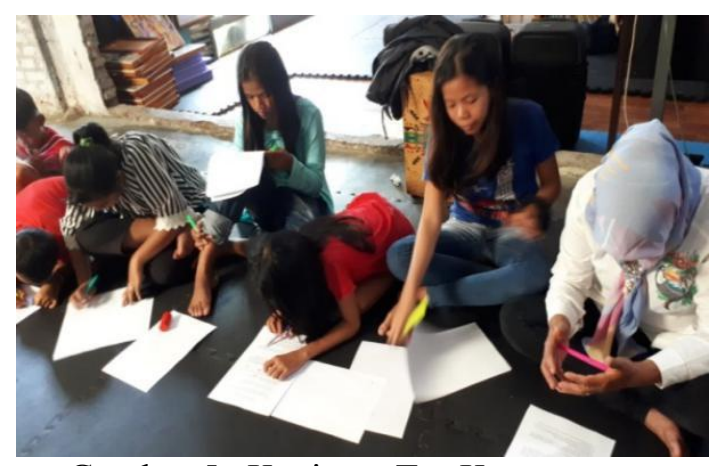

Gambar 5. Kegiatan Tes Kemampuan Membaca Pemahaman

Hasil dari tes membaca pemahaman dari kegiatan Strategi CALLA tersebut cukup baik.

Tabel Kemampuan Membaca Pemahaman dengan Strategi CALLA di Tanah Ombak

\begin{tabular}{cccc}
\hline No & Nama & Pretes & Postes \\
\hline 1 & Fahri & 20 & 70 \\
\hline 2 & Rachel Gemi & 100 & 100 \\
\hline 3 & Willa Marwendi & 100 & 100 \\
\hline 4 & Des & 30 & 60 \\
\hline 5 & Rahmalina & 80 & 80 \\
\hline 6 & Reva Novilanti & 60 & 90 \\
\hline 7 & Aira Resti & 60 & 80 \\
\hline 8 & Alya Humaira & 40 & 50 \\
\hline 9 & Adek & 70 & 80 \\
\hline 10 & Aldo & 40 & 90 \\
\hline 11 & Edo & 60 & 90 \\
\hline & Rata-rata & 60 & 80,9 \\
\hline
\end{tabular}


Berdasarkan tabel tersebut, peningkatan kemampuan pemahaman anakanak Tanah Ombak cukup signifikan dari sebelum dilaksanakan Strategi CALLA dengan setelah dilaksanakan Strategi CALLA, yaitu dari rata-rata 60 menjadi 80,9. Kegiatan Strategi CALLA juga dapat meningkatkan motivasi membaca dan rasa ingin tau anak. Hal tersebut terlihat dari antusias anak-anak mengikuti kegiatan tersebut.

Startegi CALLA dalam kegiatan membaca pemahaman sebagai salah satu kegiatan berpikir yang melatih anak-anak komunitas untuk berpikir kritis. Seperti yang diungkapkan Krismanto (2015) bahwa kegiatan membaca tidak hanya aktivitas melafalkan bacaan. Akan tetapi, kegiatan berpikir kritis terhadap bacaan seperti mampu menjawab pertanyaan dan menceritakan kembali isi bacaan dengan bahasa yang kreatif.

Tujuan dari PKM melalui kegiatan literasi dengan Strategi CALLA di Tanah Ombak cukup tercapai karena kegiatan diikuti anak-anak komunitas dengan aktif dan antusias yang tinggi. Selain itu, hasil tes juga menunjukkan hasil yang memuaskan yang diharapkan dapat melatih meningkatkan kemampuan membaca anak-anak komunitas yang bisa berguna untuk meningkatkan prestasi akademik mereka di sekolah dan meningkatkan semangat literasi mereka di Tanah Ombak.

Pelaksanaan kegiatan membaca pada mitra 1 dengan mitra 2, yaitu Lentera Kuning sedikit berbeda pada akhir kegiatan. Hal tersebut dengan pertimbangan peserta yang mengikuti kegiatan tidak lagi anak sekolah yang berorientasi pada peningkatan semangat literasi dan nilai akademik, tetapi diikuti oleh peserta masyarakat pengunjung dan mahasiswa.

Pada mitra 2, yaitu Lentera Kuning telah dilaksanakan pada tanggal 8 Maret 2018 yang diikuti oleh sembilan belas orang masyarakat dan mahasiswa yang berkunjung ke Masjid Taqwa Muhammadyah Padang. Dengan tidak mengubah tujuan dan target kegiatan untuk peningkatan motivasi literasi masyarakat, kami pelaksana mengubah tes akhirnya dalam bentuk menulis, yaitu menulis puisi. Tujuan dari menulis puisi tersebut adalah agar peserta terbuka wawasan dan imajinasinya bahwa dari hasil dari kegiatan membaca juga dapat dituangkan dalam bentuk tulisan bahkan sebuat karya, salah satunya karya sastra puisi.
Kegiatan literasi dengan strategi CALLA yang dilakukan di Lentera Kuning tidak jauh berbeda dengan yang dilakukan di Tanah Ombak. Kegiatan dilakukan melalui lima tahap.

Tahap pertama, yaitu tahap persiapan. Tahap ini dilakukan beberapa kegiatan prabaca dimulai dengan mengidentifikasi dan merefleksikan pengetahuan sebelum mengenal teks yang akan dibaca seperti melakukan skemata dengan mengidentifikasi pengetahuan perihal tema teks yang akan dibaca, yaitu carita rakyat Batu Malin Kundang, memberikan beberapa informasi tentang teks kemudian diminta untuk mengemungkakan pengetahuan tentang informasi Malin Kundang tersebut. Selanjutnya, diberikan teks lalu ditugaskan untuk mengidentifikasi melihat judul, bagian awal, dan membaca sekilas teks tersebut, kemudian diminta untuk mengemungkakan prediksi isi teks secara umum dan menanyakan alasan tentang prediksi tersebut. Terkahir, menanyakan kepada tentang tujuan membaca teks tersebut dengan mencatatnya dijurnal. Tahap ini diikuti oleh peserta dengan aktif yang terlihat dari banyaknya yang berpastisipasi dalam tanya jawab.

Tahap kedua, yaitu tahap presentasi. Tahap ini dilakukan dengan memberi informasi baru yang berhubungan dengan teks yang akan dibaca melalui media-media yang menarik. Pemberian media-media yang menarik dilakukan dengan menampilkan gambar-gambar yang berhubungan dengan teks, yaitu gambar batu Malin Kundang.

Tahap ketiga, yaitu tahap praktik. Tahap ini dilakukan dengan aktif membaca dalam hati dan mulai berlatih menemukan informasi baru. Selanjutnya, untuk memahami isi teks dilakukan diskusi kelompok perihal teks yang telah dibaca. Dalam kegiatan kelompok tersebut, pemimpin diskusi mengemungkakan rangkuman teks berdasarkan pemahamannya kemudian mendiskusikan ketepatan isi teks dan kesulitan dalam memahami teks dalam kelompok. Selanjutnya, dibuat kesimpulan secara kelompok perihal isi teks.

Tahap keempat, yaitu evaluasi. Tahap ini dilakukan dengan mengevaluasi teks tersebut dengan membandingkan skemata, informasi baru, dan informasi baru tentang isi teks. Tahap ini dilakukan dengan antusia oleh anak-anak komunitas dengan mengumpulkan semua informasi yang mereka peroleh dari 
sebelum, sedang, dan setelah membaca teks tentang Batu Malin Kundang.

Tahap kelima, yaitu tahap tindak lanjut. Tahap ini merupakan tahap pascabaca dengan menentukan kesimpulan dari kegiatan membaca dengan ketercapaian tujuan membaca yang telah ditentukan sebelumnya.

Setelah kelima tahap kegiatan Startegi CALLA dilaksanakan. Peserta melaksanakan tes dengan diberikan beberapa teks yang menjadi sumber ide untuk menulis puisi. Berikut foto-foto kegiatan literasi dengan Strategi CALLA dan hasil puisi yang ditulis peserta setelah kegiatan membaca.

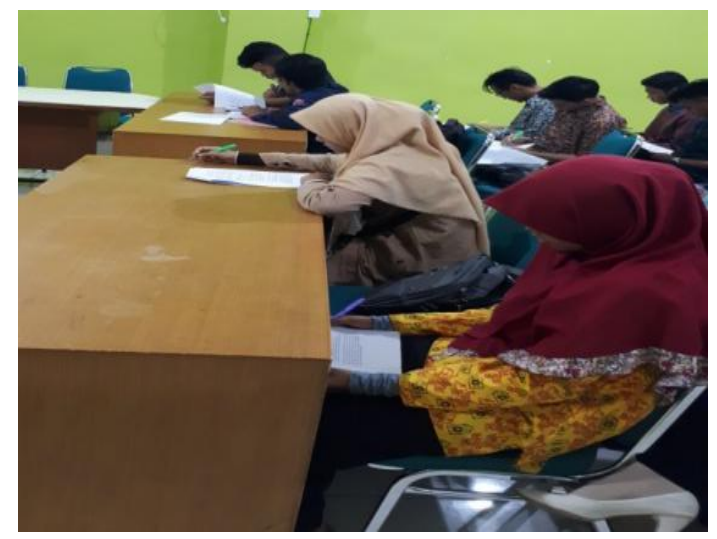

Gambar 6. Kegiatan Tahap 3 Praktik Membaca dalam Startegi CALLA

Hasil dari kegiatan literasi di Lentera Kuning berupa karya sastra puisi yang ditulis masing-masing peserta. Puisi yang ditulis bertemakan dari teks-teks yang diberikan. Setelah dilaksanakan kegiatan membaca dengan strategi CALLA, peserta ditugaskan untuk menulis puisi sebagai wujud hasil dari kegiatan tersebut. Berikut cuplikan beberapa karya dari peserta.

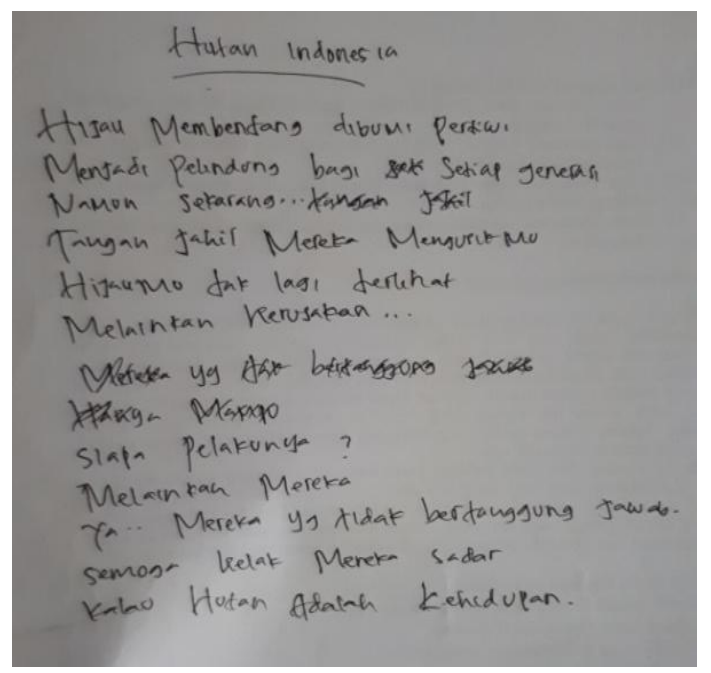

Gambar 7 Hasil Kegiatan Literasi (Menulis Puisi) karya Ovi Yulia Sari

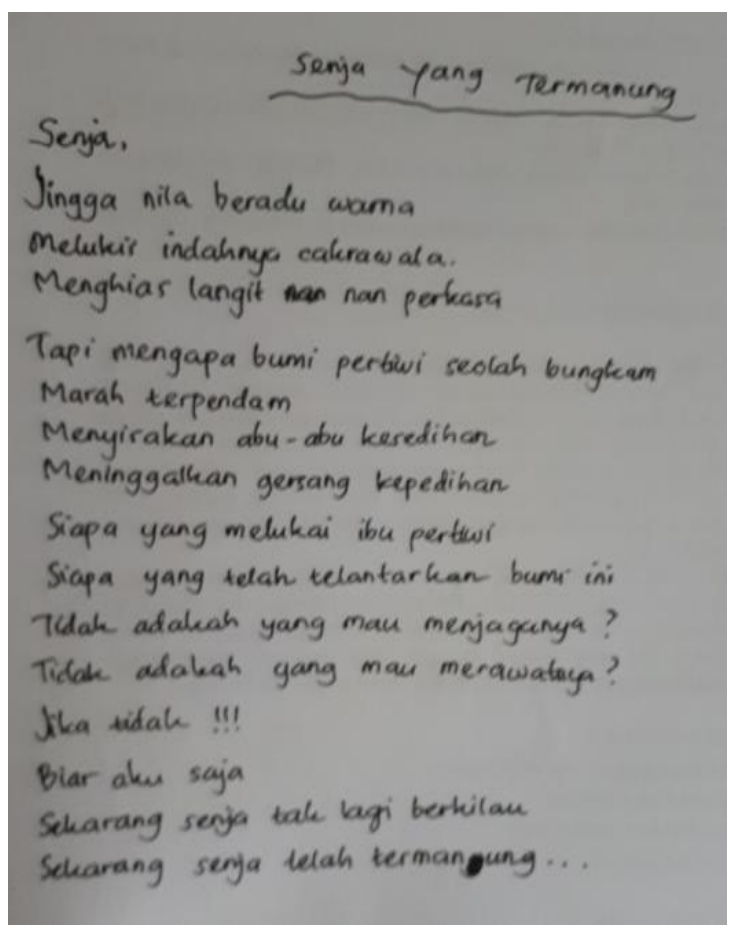

Gambar 8 Hasil Kegiatan Literasi (Menulis Puisi) karya Deby Nugraha

Puisi yang dihasilkan dari kegiatan ini ada sembilan belas judul dengan tema yang berbeda-beda. Hasilnya cukup baik yang dilihat dari kecocokan isi puisi dengan tema yang diberikan, pilihan kata yang digunakan pun cukup bervariasi, dan pesan yang terkandung dalam puisi pun cukup mendalam yang dapat menggugah imajinasi.

Tujuan dari PKM melalui kegiatan literasi dengan Strategi CALLA di Lentera Kuning cukup tercapai karena kegiatan diikuti peserta dengan aktif dan antusias yang tinggi. Selain itu, hasil tes juga menunjukkan hasil yang memuaskan yang diharapkan dapat melatih meningkatkan kemampuan membaca peserta yang bisa berguna untuk meningkatkan prestasi akademik dan meningkatkan semangat literasi mereka di Lentera Kuning.

\section{KESIMPULAN \& SARAN}

Kegiatan literasi berupa peningkatan kemampuan membaca dengan Strategi CALLA terhadap kedua mitra masyarakat terlaksana dengan baik dengan hasil yang memuaskan. Peningkatan minat dan motivasi mitra terhadap kegiatan membaca juga terlihat dari antusias peserta pada yang tinggi untuk 
mengikuti dan melaksanakan kegiatan yang diprogramkan pengusul.

Pada mitra 1 di Tanah Ombak, hasil diperoleh adalah peningkatan hasil tes membaca pemahaman peserta dari sebelum dilakukan Strategi CALLA dengan setelah dilakukan Startegi CALLA. Pada mitra 2 di Lentera Kuning, hasil diperoleh berupa karya sastra puisi yang tema-temanya diperoleh dari teks-teks yang diberikan saat pelaksanaan strategi CALLA.

\section{DAFTAR PUSTAKA}

Annisa, Witri dan Rio Rinaldi. 2017. Kemampuan Membaca Pemahaman dengan Strategi Cognitive Academic Languange Learning Approach (CALLA) Berbasis Kearifan Lokal Siswa Kelas VII SMP Negeri 18 Padang. Jurnal Puitika Vol.13 No. 2, pp 220227.

Annisa, Witri dan Rio Rinaldi. 2017. Pembelajaran Membaca Pemahaman dengan Strategi Cognitive Academic Languange Learning Approach (CALLA) Berbasis Kearifan Lokal. Jurnal Dialektika Vol. 4 No.2, pp 240 258

Dalam http://journal.uinjkt.ac.id/index.php/dial ektika/index.php. diunduh pada 7 Juni 2018.

BPS. 2014. Luas Daerah dan Jumlah Penduduk Kota Padang. Dalam www.sumbar.bps.go.id. diunduh 23 Mei 2016.

Chamot, Anna. 1995. Implementing The Cognitive Academic Language Learning Approach : CALLA In Arlington Virginia. THE BILINGUAL RESEARCH JOURNAL Summer/Fall. Vol. 19, Nos. 3 \& 4, pp. 379-394. Diunduh 2 April $\underline{2016}$

Imansyah, Nur. 2016. Anggota DPR sebut minat baca penduduk Indonesia rendah. News.

Dalam http://www.antaranews.com/berita/5561 86/anggota-dpr-sebut-minat-bacapenduduk-indonesia-rendah. Diunduh 18 Mei 2016.

Krismanto, Wawan, Abdul Khalik, dan Syayidiman. 2015. Meningkatkan Kemampuan Membaca Pemahaman melalui Metode SQ3R pada Siswa Kelas V SD Negeri 46 Parepare. Jurnal
Publikasi Pendidikan Vol. 5 No. 3, pp 244-242. Dalam http://ojs.unm.ac.id/pubpend/articel/vie w/1616/675. Diunduh 25 Sepetember 2018.

Suhariyanto, Kacuk. 2015. Indeks Pembangunan Manusia (IPM):(Metode Baru). Dalam http://www.bps.go.id/website/pdf publi kasi/Bahan-Sosialisasi-IPM-MetodeBaru.pdf. Diunduh 18 Mei 2016.

Marimuthu, R, Chittra Muthusamy, dan Jeyamahla Veeravagu. 2011. Metacognitive Strategy Training through The Cognitive Academic Language Learning Approach (CALLA) as a Way to Improve Reading Comprehension Performance among Students of an English Language Course at UiTM Penang. Malaysian Journal of ELT Research. Vol.7 (1). Diunduh tanggal 3 Februari 2017. 